\title{
LITERASI KEUANGAN DAN PERENCANAAN KEUANGAN PADA DANA PENDIDIKAN ANAK
}

\author{
Maria Rio Rita dan Benny Santoso \\ Fakultas Ekonomika dan Bisnis Universitas Kristen Satya Wacana \\ maria.riorita@staff.uksw.edu
}

\begin{abstract}
The purpose of this study is to analyze financial literacy and financial planning on educational funds for children among housewives. The participants of this study are 100 housewives in Sidorejo Lor, Salatiga. Data collection technique is using distribution questionnaires and conducting interviews to obtain more in-depth information. The collected data was analyzed using statistic descriptive analysis approach to investigate the level of financial literacy and financial planning on the children educational funds. Based on the results of the analysis, it can be concluded that: 1) Level of financial literacy on planning children educational funds among housewives in Sidorejo Lor Salatiga is categorized high level; 2) The financial planning on the education of children among housewives in Sidorejo Lor, Salatiga is categorized high.
\end{abstract}

Keywords: financial literacy, financial planning, children educational funds

\begin{abstract}
Abstrak: Penelitian ini bertujuan untuk menganalisis literasi keuangan dan perencanaan keuangan pada dana pendidikan anak dikalangan ibu rumah tangga. Responden dalam penelitian ini adalah 100 ibu rumah tangga yang tinggal di Kelurahan Sidorejo Lor, Salatiga. Data diperoleh melalui penyebaran kuesioner dan wawancara untuk menggali informasi yang lebih mendalam. Data yang terkumpul dianalisis dengan menggunakan analisis statistik deskriptif yaitu untuk mengetahui tingkat literasi keuangan dan perencanaan keuangan pada dana pendidikan anak. Berdasarkan hasil analisis yang dilakukan diperoleh hasil sebagai berikut: 1) Tingkat literasi keuangan pada perencanaan dana pendidikan anak dikalangan ibu rumah tangga di Sidorejo Lor Salatiga tergolong tinggi; 2) Perencanaan keuangan pada dana pendidikan anak dikalangan ibu rumah tangga di kelurahan Sidorejo Lor Salatiga juga tergolong tinggi.
\end{abstract}

Kata Kunci : literasi keuangan, perencanaan keuangan, dana pendidikan anak

\section{PENDAHULUAN}

Otoritas Jasa Keuangan (OJK) terus berusaha mengembangkan berbagai inovasi program literasi keuangan untuk meningkatkan pemahaman dan penggunaan masyarakat terkait produk dan layanan sektor keuangan. Survei nasional tentang literasi keuangan yang dilakukan oleh OJK pada 2013 di 20 provinsi dengan jumlah 8.000 responden secara umum menunjukkan tingkat literasi keuangan masyarakat Indonesia baru sebesar 21,8\% . Adapun indeks literasi masyarakat golongan $\mathrm{C}, \mathrm{D}$, dan $\mathrm{E}$ (masyarakat berpenghasilan rendah/low income) sebesar $18,71 \%$. Angka ini masuk kategori rendah jika dibanding tingkat literasi keuangan negara lain seperti Philipina (27\%), Malaysia (66\%), Thailand (73\%) dan Singapura (98\%) (http://www.ojk.go.id). Ketua Dewan Komisioner OJK, Muliaman D. Hadad mengatakan OJK menargetkan ibu rumah tangga dalam pengenalan industri jasa keuangan karena ibu rumah tangga memegang peran utama dalam pengaturan keuangan di keluarga (http://bisnis.liputan6.com). Salah satu yang disosialisasikan OJK 
adalah mengenai perencanaan dana pendidikan.Berdasarkan sosialisasi OJK tersebut untuk mempersiapkan dana pendidikan masa depan anak yaitu bisa dengan menggunakan instrumen investasi seperti tabungan pendidikan bank, asuransi pendidikan, dana pendidikan melalui investasi obligasi, reksadana, saham dan logam mulia pegadaian (Otoritas Jasa Keuangan, 2013:47-48). Perencanaan keuangan pada dana pendidikan anak dirasa penting mengingat biaya pendidikan di Indonesia cenderung naik setiap tahun. Untuk itu, orang tua sebaiknya mempersiapkan biaya pendidikan anak sejak dini agar bisa memberikan pendidikan terbaik bagi putra-putrinya. Menurut kalkulasi para perencana keuangan, biaya pendidikan di Indoensia rata-rata meningkat sekitar 15\% sampai $20 \%$ per tahun (http://personalfinance.kontan.co.id).

Dalam membuat perencanaan keuangan dibutuhkan literasi keuangan, tidak terkecuali bagi ibu rumah tangga terkhusus saat mempersiapkan dana pendidikan putra putrinya. Widiyati (2012) mengungkapkan seseorang perlu memiliki pengetahuan, sikap dan implementasi keuangan pribadi yang sehat yang dikenal dengan literasi keuangan. Byrne (2007) menemukan bahwa pengetahuan keuangan yang rendah akan menyebabkan pembuatan rencana keuangan yang salah, dan menyebabkan bias dalam pencapaian kesejahteraan di saat usia tidak produktif lagi. Sejalan dengan hal itu, Hailwood (2007) sebagaimana dikutip Yulianti dan Silvy (2013) menyatakan bahwaliterasi keuangan akan mempengaruhi bagaimana orang menabung, meminjam, berinvestasi dan mengelola keuangan lebih jauh, kecakapan finansial disini juga lebih menekankan pada kemampuan untuk memahami konsep dasar dari ilmu ekonomi dan keuangan, hingga bagaimana menerapkannya secara tepat.

Beberapa studi telah mengkaji literasi keuangan, Chen dan Volpe (1998) meneliti literasi keuangan melalui pemahaman dan keputusan keuangan dikalangan mahasiswa di Amerika. Behrman, et al (2012) meneliti mengenai bagaimana literasi keuangan mempengaruhi peningkatan kekayaan dikalangan rumah tangga, selanjutnya Lusardi dan Mitchell (2014) meneliti mengenai literasi keuangan mengenai teori dan praktek. Navickas, et al (2014) mengkaji literasi keuangan ternyata mampu mempengaruhi manajemen keuangan pribadi pada rumah tangga. Sementara Rosaline (2014) mencoba mengkaitkan tingkat literasi keuangan dan alokasi pendapatan dikalangan ibu rumah tangga.

Berdasarkan hasil riset sebelumnya, masih belum ada yang mencoba menyoroti mengenai tingkat literasi keuangan pada perencanaan dana pendidikan dikalangan ibu rumah tangga. Adanya senjang penelitian dan fenomena yang ada, masih terbuka peluang untuk meneliti lebih lanjut mengenai literasi keuangan mengenai perencanaan keuangan pada dana pendidikan anak dikalangan ibu rumah tangga. Dari latar belakang tersebut maka dapat dirumuskan masalah penelitian sebagai berikut (a) Bagaimana tingkat literasi keuangan yang dimiliki kalangan ibu rumah tangga? (b) Apakah perencanaan keuangan dana pendidikan anak dianggap penting bagi kalangan ibu rumah tangga?

Manfaat penelitian ini adalah untuk melihat literasi keuangan dan perencanaan keuangan pada dana pendidikan anak dikalangan ibu rumah tangga sehingga dapat memberikan masukan bagaimana mempersiapkan dan mengelola dana pendidikan anak.

\section{KAJIAN TEORI}

Literasi Keuangan. Chen dan Volpe (1998) mendefinisikan literasi keuangan sebagai pengetahuan untuk mengelola keuangan dalam pengambilan keputusan keuangan. 
Pengetahuan keuangan yaitu pengetahuan mengenai konsep-konsep dasar keuangan yaitu seperti pengetahuan dasar mengenai bunga majemuk, perbedaan nilai nominal dan nilai riil, pengetahuan dasar mengenai diversifikasi risiko, nilai waktu dari uang dan lain-lain (Pritazhara dan Sriwidodo, 2015). Literasi keuangan merupakan salah satu kebutuhan dasar bagi setiap orang agar terhindar dari masalah keuangan (Rasyid, 2012). Literasi keuangan sangat penting dalam meningkatkan kesejahteraan individu, dimana pengetahuan keuangan yang dimiliki dapat menentukan individu dalam mengambil keputusan keuangan (Margaretha dan Pambudi, 2015).

Perencanaan Keuangan. Senduk (2000) mendefinisikan perencanaan keuangan adalah proses merencanakan tujuan-tujuan keuangan jangka pendek maupun jangka panjang (Yohnson, 2004). Wibawa (2003) mengungkapkan manfaat perencanaan keuangan tersebut yang pertama perencanaan keuangan tidak menjanjikan orang menjadi kaya mendadak, akan tetapi lebih pada pendisiplinan langkah untuk mengendalikan diri dan menyediakan kondisi finansial masa depan terbaik bagi diri sendiri dan keluarga secara efisien dan efektif sesuai dengan kemampuan finansial saat ini, yang kedua jaminan keuangan yang aman (secure) dan yang ketiga perencanaan keuangan keluarga akan membantu secara efisien dan efektif meraih cita-cita finansial.

Sembel, et al (2003) dalam Suhartini dan Renanta (2007) menjelaskanbeberapa alasan mengapa perencanaan keuangan perlu dilakukan oleh individu maupun keluarga, yaitu untuk melindungi diri sendiri dan keluarga dari berbagai risiko yang berdampak secara finansial (seperti kecelakaan, penyakit, kematian, dan tuntutan hukum), mengurangi hutang-hutang pribadi / keluarga, membiayai kehidupan saat tidak lagi berada dalam rentang usia produktif, ini berkaitan dengan naiknya tingkat ekspektasi hidup rata-rata manusia di suatu negara, membayar biaya-biaya yang diperlukan untuk membesarkan anak, menyediakan biaya pendidikan anak sampai ke perguruan tinggi, membayar biaya pernikahan, membeli kendaraan, membeli rumah, mampu menentukan masa pensiun dengan gaya hidup yang kita inginkan, membayar biaya-biaya perawatan yang bersifat jangka panjang, dan mewariskan kesejahteraan kepada generasi berikutnya.

Goss (2001) menyatakan untuk mencapai hasil yang optimal ketika mengerjakan sebuah perencanaan keuangan, seorang perencana keuangan harus: (a) Menetapkan tujuan keuangan yang terukur dan mempunyai jangka waktu. Setiap tujuan yang sudah ditetapkan akan mempunyai konsekuensi tertentu terhadap cashflow yang akan dibuat; (b) Evaluasi kembali kondisi keuangan secara periodik. Tujuan keuangan boleh berganti dengan berjalannya waktu karena perubahan pola hidup seseorang seperti menikah, kenaikan pangkat, atau mempunyai anak; (c) Mulai perencanaan sedini mungkin. Mengembangkan kebiasaan perencanaan keuangan yang baik, seperti menabung, anggaran, investasi, dan mengevaluasi secara teratur, kehidupan seseorang dapat berubah dan dapat mengatasi keadaan darurat; (d) Penetapan tujuan keuangan haruslah realistis. Tujuan keuangan tersebut memerlukan suatu proses yang panjang karena adanya ketidakpastian dan risiko seperti terjadi inflasi, perubahan harga saham, perubahan tingkat suku bunga yang akan mempengaruhi hasil perencanaan keuangan; (e) Mencapai tujuan keuangan memerlukan perjuangan. Jadi suatu perencanaan keuangan tidak berhenti pada sebuah perencanaan melainkan harus terus diikuti perkembangannya, inilah yang disebut sebagai suatu proses. Kapoor, et al(2011) menjabarkan enam langkah dalam melakukan perencanaan keuangan yaitu : (a) Menentukan kondisi keuangan saat ini yaitu meliputi pendapatan, biaya hidup dan hutang; (b) Membuat tujuan keuangan. Dalam menentukan tujuan keuangan harus memperhatikan aspek SMART yaitu specific (menetapkan tujuan keuangan yang ingin 
dicapai secara spesifik), measurable (berapa banyak uang yang dibutuhkan dalam jangka waktu tertentu), action-oriented (tindakan berorientasi), realistic (tujuan keuangan yang ingin dicapai harus realistis/ sesuai dengan kemampuan), dan time-based (kerangka waktu untuk mencapai tujuan keuangan); (c) Identifikasi alternatif-alternatif sebelum membuat keputusan; (d) Lakukan evaluasi terhadap alternatif keputusan yang diambil; (e) implementasikan program perencanaan keuangan; (f) meninjau dan merevisi rencana keuangan.

Perencanaan Keuangan Dana Pendidikan Anak. Dana pendidikan adalah dana yang dialokasikan terpisah untuk memenuhi kebutuhan pendidikan anak dimasa mendatang(Akbar, 2007).Alasan pentingnya mempersiapkan perencanaan keuangan pada dana pendidikan anak yaitu mengingat biaya pendidikan dari tahun-ketahun terus mengalami peningkatan, naiknya biaya hidup dari tahun ketahun, keadaan perekonomian tidak akan selalu baik, fisik manusia tidak akan selalu sehat dan banyaknya alternatif produk keuangan adalah alasan mengapa keluarga perlu menyiapkan perencanaan keuangan pada dana pendidikan anak (Senduk, 2008 dalam Unola dan Linawati, 2014). Beberapa kesalahan yang terjadi dalam merencanakan dana pendidikan antara lain tidak memperkirakan jumlah biaya pendidikan anak dimasa depan dan tidak melindungi tabungan dengan unsur proteksi(Senduk, 2007).

OJK menyarankan keluarga sebaiknya menyisihkan dana pendidikan sebesar $20 \%$ dari penghasilan (OJK, 2013:47), hal ini sendiri untuk mengimbangi kenaikan biaya pendidikan yang dari tahun-ketahun mengalami kenaikan kisaran anrata $15 \%$ sampai $20 \%$. Ada beberapa solusi untuk mempersiapkan dana pendidikan masa depan anak-anak yaitu dengan menggunakan instrumen investasi seperti tabungan pendidikan bank, asuransi pendidikan, dana pendidikan melalui investasi (obligasi, reksadana, saham, dan logam mulia pegadaian) (OJK, 2013:48).

Literasi Keuangan dan Perencanaan Keuangan Dana Pendidikan Anak. Septiani dan Rita (2013) mengatakan didalam merencanakan keuangan pribadi, individu dituntut pintar dalam mengelola keuangan, untuk itulah pengetahuan terhadap keuangan sangat penting. Senada dengan Widiyati (2012), seseorang perlu memiliki pengetahuan, sikap dan implementasi keuangan pribadi yang sehat yang dikenal dengan literasi keuangan dalam mengelola uang. Melihat kenyataan biaya pendidikan dari tahun-ketahun yang mengalami peningkatan, kemampuan orang tua dalam membuat perencanaan keuangan akan sangat bergantung pada pengetahuan orang tua dalam memilih instrumen produk dan jasa keuangan. Sebagaimana yang dikemukakan OJK, masih banyak konsumen dan/atau masyarakat yang less literate atau not literate sehingga diperlukan peningkatan literasi keuangan sebagai salah satu cara meningkatkan pengetahuan, keyakinan, dan keterampilan konsumen dan/atau masyarakat agar konsumen dan/atau masyarakat dapat menentukan produk dan jasa keuangan yang sesuai dengan kebutuhan mereka, memahami dengan benar manfaat dan risikonya, mengetahui hak dan kewajiban serta meyakini bahwa produk dan jasa keuangan yang dipilih tersebut dapat meningkatkan kesejahteraan mereka.Pemahaman mengenai instrumen produk dan jasa keuangan tersebut akan mempermudah keluarga untuk membuat perencanaan keuangan pada pengalokasian dana pendidikan anak(www.ojk.go.id). 


\section{METODE}

Populasi dan Sampel. Populasi dalam penelitian ini adalah ibu rumah tangga yang bekerja dan tidak bekerja di Kelurahan Sidorejo Lor, Salatiga. Data BPS Salatiga mencatat jumlah rumah tangga di Kelurahan Sidorejo Lor sebanyak 4.656 rumah tangga pada tahun 2013. Lokasi tersebut dipilih karena tingkat pendidikan masyarakat Kelurahan Sidorejo Lor, Salatiga yang kebanyakan sudah berpendidikan SLTA keatas. semakin tinggi tingkat pendidikan maka semakin tinggi tingkat pengetahuan keuangan, sehingga diharapkan memiliki tingkat literasi keuangan yang tinggi dan akan membantu dalam merencanakan dana pendidikan anak(Lusardi dan Mitchell, 2014).

Tabel 1. Tingkat Pendidikan Masyarakat Kelurahan Sidorejo Lor, Salatiga Tahun 2012

\begin{tabular}{l|r|r|r|}
\hline Tingkatan Pendidikan & Laki-Laki (orang) & Perempuan (orang) & Jumlah (Orang) \\
\hline Tamat SMP/sederajat & 854 & 1.205 & 2.059 \\
\hline Tamat SMA/sederajat & 1.929 & 2.131 & 4.060 \\
\hline Tamat D-3/sederajat & 1.149 & 1.050 & 2.199 \\
\hline Jumlah Total (Orang) & 3.932 & 4.386 & 8.318 \\
\hline
\end{tabular}

Sumber: http://prodeskel.binapemdes.kemendagri.go.id/

Sampel dalam penelitian ini diambil dengan menggunakan metode nonprobability sampling dengan teknikconvenience sampling yaitu prosedur sampling dengan memilih berdasarkan pertimbangan paling mudah dijumpai atau di akses (Hanafi, 2007). Dari hasil perhitungan tersebut maka sampel ibu rumah tangga yang di ambil adalah sebanyak 100 orang. Formula yang digunakan dalam penelitian ini adalah menggunakan formula yang dikemukakan Yamane (1973) dalam Supramono dan Utami (2004) yaitu sebagai berikut :

$n=\frac{N}{\left(N d^{2}+1\right)}$

Dimana: $\mathrm{n}$ : jumlah sampel

$\mathrm{N} \quad$ : jumlah populasi

d : presisi yang ditetapkan $10 \%$

$n=\frac{4.656}{\left(4.656(10 \%)^{2}+1\right)}$

$n=97,89 \approx 100$ orang

Metode Pengumpulan Data. Instrumen penelitian didistribusikan kepada ibu rumah tangga melalui berbagai cara, seperti saat sedang berada di sekolah yaitu saat sedang menunggu jam pulang sekolah anak; mendatangi langsung ibu-ibu yang berada di rumah ataupun dengan menitipkan kuesioner kepada pihak anggota keluarga yang dikenal oleh peneliti. Proses pertama pengumpulan data yaitu untuk uji pilot test dengan mengumpulkan sebanyak 30 kuesioner yaitu dilakukan selama kisaran dua minggu, kemudian yaitu melakukanproses pengumpulan data kuesioner untuk uji analisis data selama kisaran satu bulan. 
Pengukuran Konsep. Variabel yang diukur pada penelitian ini adalah literasi keuangan dan perencanaan keuangan pada dana pendidikan anak. Pengukuran variabel literasi keuangan mengacu pada Chen dan Volpe (1991), yang meliputi pengetahuan dan keputusan menyangkut pengetahuan mengenai perencanaan keuangan pada dana pendidikan anak dan pengambilan keputusan keuangan pada perencanaan dana pendidikan anak. Pengukuran perencanaan keuangan pada dana pendidikan anak mengacu pada Akbar (2007) dalam Unola dan Linawati (2014) yaitu dana yang dialokasikan terpisah untuk memenuhi kebutuhan pendidikan anak dimasa mendatang.

Tabel 2. Pengukuran Variabel

\begin{tabular}{|c|c|c|}
\hline Variabel & Definisi & Indikator Pengukuran \\
\hline $\begin{array}{l}\text { Literasi Keuangan } \\
\text { (Chen dan Volpe, 1998) }\end{array}$ & $\begin{array}{l}\text { Sebagai pengetahuan } \\
\text { untuk mengelola } \\
\text { keuangan dalam } \\
\text { pengambilan } \\
\text { keputusan keuangan }\end{array}$ & $\begin{array}{l}\text { - Pengetahuan perencanaan keuanganpada dana } \\
\text { pendidikan } \\
\text {-Pengetahuan umum } \\
\text {-Produk dan jasa keuangan } \\
\text {-Nilai waktu uang } \\
\text { - Pengambilan keputusan } \\
\text { mengenaiperencanaan keuangan pada dana } \\
\text { pendidikan } \\
\text {-Apakah anda menetapkan tujuan yang hendak } \\
\text { dicapai pada saat membuat perencanaan dana } \\
\text { pendidikan anak } \\
\text {-Apakah anda melakukan perhitungan } \\
\text { mengenai perkiraan biaya pendidikan yang } \\
\text { dibutuhkan dimasa depan } \\
\text {-Apakah anda melakukan evaluasi terhadap } \\
\text { perencanaan dana pendidikan }\end{array}$ \\
\hline $\begin{array}{l}\text { Perencanaan Keuangan } \\
\text { Dana Pendidikan Anak } \\
\text { (Akbar, } 2007 \text { dalam } \\
\text { Unola dan Linawati, } \\
\text { 2014) }\end{array}$ & $\begin{array}{l}\text { Dana yang } \\
\text { dialokasikan terpisah } \\
\text { untuk memenuhi } \\
\text { kebutuhan } \\
\text { pendidikan anak } \\
\text { dimasa mendatang }\end{array}$ & 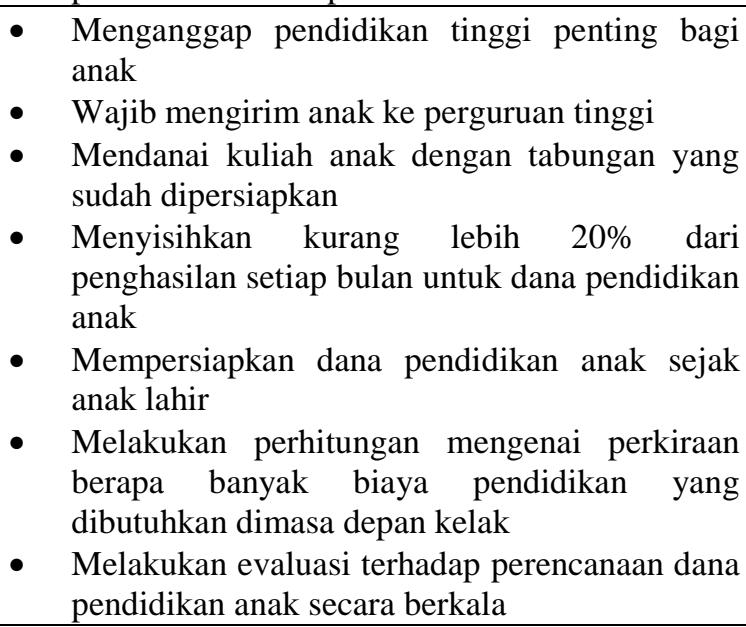 \\
\hline
\end{tabular}

Teknik Analisis. Pilot test untuk melakukan uji reliabilitas dan uji validitasdilakukan terhadap 30 responden. Suatu construct dikatakan reliable jika memberikan nilai cronbach alpha> 0.7 dan suatu indikator dikatakan valid jika r-hitung > r-tabel (Wijaya, 2012). Pertanyaan pada variabel literasi keuangan dalam kuesioner ini mengacu pada definisi Chen dan Volpe (1998) yang disesuaikan dengan perencanaan dana pendidikan anak yang terdiri dari pertanyaan mengenai pengetahuan untuk mengelola dana pendidikan anak (berisi soal pilihan ganda) dan pengambilan keputusan keuangan pada dana pendidikan 
anak yang diadopsi dari Chen dan Volpe (1998), Senduk (2007) serta Kapoor et al (2011). Pengelompokan skor dilakukan dengan menghitung jawaban benar yang dikelompokkan ke dalam dua kategori presentase dari seluruh responden. Kategori pertama mencakup < $50 \%$ (tingkat pengetahuan rendah) dan yang kedua $\geq 50 \%$ (tingkat pengetahuan tinggi).

Pada variabel perencanaan keuangan pada dana pendidikan anak mengacu pada kuesioner Unola dan Linawati (2014), Rini (2006), Otoritas Jasa Keuangan (2013: 47) serta dengan menggunakan skala likert 5 skor, yaitu 1 untuk sangat tidak setuju, 2 untuk tidak setuju, 3 untuk netral, 4 untuk setuju, 5 untuk sangat setuju. Dari jawaban responden mengenai perencanaan dana pendidikan anak dapat dikategorikan $<3$ rendah dan $\geq 3$ tinggi. Semakin tinggi rata-rata perencanaan dana pendidikan anak berarti perencanaan keuangan pada dana pendidikan dianggap penting. Dari data yang telah dikumpulkan kemudian dianalisis dengan statistik deskriptif yaitu untuk melihat tingkat literasi keuangan dan perencanaan keuangan pada dana pendidikan anak.

\section{HASIL DAN PEMBAHASAN}

Pilot Test. Berikut ini adalah hasil pilot testterhadap 30 responden ibu rumah tangga di Kelurahan Sidorejo Lor Salatiga.

Tabel 3. Uji Reliabilitas

\begin{tabular}{ccc}
\hline Variabel & cronbach alpha & Keterangan \\
\hline $\begin{array}{c}\text { Perencanaan Dana Pendidikan } \\
\text { Anak }\end{array}$ & 0,739 & Reliable \\
\hline
\end{tabular}

Hasil uji reliabilitasdikatakatakan reliable jika memberikan nilai cronbach alpha> 0.7 (Wijaya,2012). Sehingga berdasarkan data tabel dua maka variabel perencanaan dana pendidikan anak dikatakan reliable.

Tabel 4. Uji Validitas

\begin{tabular}{|c|c|c|c|c|c|}
\hline No & Indikator & r-Hitung & & r-Tabel & Keterangan \\
\hline 1 & $\begin{array}{l}\text { Menganggap pendidikan tinggi penting bagi } \\
\text { anak }\end{array}$ & $0.460^{*}$ & $>$ & 0.361 & Valid \\
\hline 2 & Wajib mengirim anak ke perguruan tinggi & 0.355 & $<$ & 0.361 & Tidak Valid \\
\hline 3 & $\begin{array}{l}\text { Mendanai kuliah anak dengan investasi yang } \\
\text { sudah dipersiapkan }\end{array}$ & $0.581 *$ & $>$ & 0.361 & Valid \\
\hline 4 & $\begin{array}{l}\text { Menyisihkan kurang lebih } 20 \% \text { dari } \\
\text { penghasilan setiap bulan untuk dana } \\
\text { pendidikan anak }\end{array}$ & $0.626^{*}$ & $>$ & 0.361 & Valid \\
\hline 5 & $\begin{array}{l}\text { Mempersiapkan dana pendidikan anak sejak } \\
\text { anak lahir }\end{array}$ & $0.410 *$ & $>$ & 0.361 & Valid \\
\hline 6 & $\begin{array}{l}\text { Melakukan estimasi biaya pendidikan yang } \\
\text { dibutuhkan dimasa depan kelak }\end{array}$ & $0.453^{*}$ & $>$ & 0.361 & Valid \\
\hline 7 & $\begin{array}{l}\text { Melakukan evaluasi terhadap perencanaan } \\
\text { dana pendidikan anak secara berkala }\end{array}$ & $0.373 *$ & $>$ & 0.361 & Valid \\
\hline
\end{tabular}


Berdasarkan hasil di Tabel 4, terdapat satu indikator yang tidak valid yaitu indikator ke dua sehingga indikator ke dua harus dihilangkan karena nilai $r$ hitung $<r$ tabel. Sehingga dalam kuesioner ini menggunakan enam indikator untuk mengukur variabel perencanaan keuangan pada dana pendidikan anak.

Karakteristik Responden. Berikut ini adalah karakteristik dari 100 responden ibu rumah tangga yang berada di Kelurahan Sidorejo Lor, Salatiga.

Tabel 5. Karakteristik Umum Responden

\begin{tabular}{cccc}
\hline Karakteristik & Kategori & Jumlah & Persentase \\
\hline Usia & $22 \leq 27$ & 2 & $2 \%$ \\
& $27 \leq 32$ & 11 & $11 \%$ \\
& $32 \leq 37$ & 24 & $24 \%$ \\
& $37 \leq 42$ & 25 & $25 \%$ \\
& $42 \leq 47$ & 23 & $23 \%$ \\
& $47 \leq 52$ & 10 & $10 \%$ \\
& $52 \leq 57$ & 5 & $5 \%$ \\
\hline Total & & 100 & $100 \%$ \\
\hline Jumlah Anak & 1 & 35 & $35 \%$ \\
& 2 & 36 & $36 \%$ \\
& 3 & 23 & $23 \%$ \\
& 4 & 4 & $4 \%$ \\
Total & 5 & 2 & $2 \%$ \\
\hline Pendidikan & & 100 & $100 \%$ \\
& SD & 1 & $1 \%$ \\
& SMP & 5 & $5 \%$ \\
& SMA & 45 & $45 \%$ \\
& Diploma & 7 & $7 \%$ \\
& S1 & 38 & $38 \%$ \\
& Pascasarjana & 4 & $4 \%$ \\
\hline Total & & 100 & $100 \%$ \\
\hline
\end{tabular}

Ibu rumah tangga yang menjadi responden pada penelitian ini berusia 22-56 tahun. Berdasarkan Peraturan Pemerintah No.45 / 2015 tentang penyelenggaraan program jaminan usia pensiun yaitu 56 tahun (Sekretariat Kabinet Indonesia, 2015). Sehingga dari data di atas rentangan usia responden yang dominan adalah 32 sampai 47 tahun atau masih bisa dikatakan pada kisaran usia produktif karena berada di bawah usia pensiun.

Dilihat dari jumlah anak sebanyak $36 \%$ responden mempunyai dua anak dan sebanyak $35 \%$ responden mempunyai satu anak, dengan jumlah anak seperti yang disarankan oleh Badan Kependudukan dan Keluarga Berencana Nasional (BKKBN) yaitu dua anak cukup akan meringankan biaya tanggungan anak yang ada.

Terkait dengan tingkat pendidikan yang paling banyak adalah lulusan SMA yaitu sebanyak $45 \%$ dan yang kedua S1 sebanyak 38\%. Tidak dapat dipungkiri syarat pendidikan minimal yang diterapkan oleh sebagian besar perusahaan sekarang yaitu tamatan SMA ke atas sehingga menjadi tuntutan bagi ibu rumah tangga untuk melanjutkan pendidikan.

Pada Tabel 6, karakteristik pekerjaan ibu rumah tangga yang menjadi responden penelitian ini mayoritas adalah wirausaha sebanyak $45 \%$, mengingat wilayah Sidorejo Lor, Salatiga dekat dengan Universitas Kristen Satya Wacana dan Akses Jalan Diponogoro 
yang merupakan area strategis untuk berwirausaha. Sedangkan sisanya memiliki karakteristik bekerja sebagai dosen, pegawai swasta, PNS, dan lainnya.

Tabel 6. Karakteristik Responden Berdasarkan Jenis Pekerjaan

\begin{tabular}{cccc}
\hline Karakteristik & Kategori & Jumlah & Persentase \\
\hline Pekerjaan & Wirausaha & 45 & $45 \%$ \\
& Mengurus Rumah & 23 & $23 \%$ \\
& Tangga & 20 & $20 \%$ \\
& Pegawai Swasta & 4 & $4 \%$ \\
& Dosen & 2 & $2 \%$ \\
& PNS & 6 & $6 \%$ \\
& Lainnya & & \\
\hline Total & & 100 & $100 \%$ \\
\hline
\end{tabular}

Tabel 7. Karakteristik Responden Berdasarkan Penghasilan

\begin{tabular}{lcccc}
\hline \multirow{2}{*}{ Penghasilan } & \multicolumn{3}{c}{ Sumber Penghasilan Rumah Tangga } \\
\cline { 2 - 5 } & \multicolumn{2}{c}{ Penghasilan Suami } & \multicolumn{2}{c}{ Penghasilan Istri } \\
\cline { 2 - 5 } & Jumlah & Persentase & Jumlah & Persentase \\
\hline Tidak Berpenghasilan & 5 & $5 \%$ & 22 & $22 \%$ \\
$<2.000 .000$ & 26 & $26 \%$ & 43 & $43 \%$ \\
$2.000 .000-4.000 .000$ & 28 & $28 \%$ & 26 & $26 \%$ \\
$4.000 .000-6.000 .000$ & 23 & $23 \%$ & 6 & $6 \%$ \\
$6.000 .000-8.000 .000$ & 10 & $10 \%$ & 3 & $3 \%$ \\
$>8.000 .000$ & 8 & $8 \%$ & 0 & $0 \%$ \\
\hline Total & 100 & $100 \%$ & 100 & $100 \%$ \\
\hline
\end{tabular}

Berdasarkan sumber penghasilan rumah tangga, responden yang ada dikategorikan sebagai penghasilan kelas menengah. Menurut Widiatmanti (2015) kelas menengah adalah seseorang yang termasuk dalam kategori dengan rentang penghasilan antara Rp 2,6 jt sampai Rp 6jt.

Tabel 8. Karakteristik Perencanaan Dana Pendidikan Anak

\begin{tabular}{cccc}
\hline Karakteristik & Kategori & Jumlah & Persentase \\
\hline Dana Yang Di & $<20 \%$ & 63 & $\mathbf{6 3 \%}$ \\
Alokasikan Untuk & $\geq 20 \%$ & 37 & $37 \%$ \\
Pendidikan Anak & & & \\
\hline Instrumen Yang & Tabungan Umum & 59 & $\mathbf{5 9 \%}$ \\
Digunakan & Asuransi Pendidikan & 35 & $\mathbf{3 5 \%}$ \\
& Tabungan Pendidikan & 19 & $19 \%$ \\
& Logam Mulia & 5 & $5 \%$ \\
& Deposito & 3 & $3 \%$ \\
& Saham & 2 & $2 \%$ \\
& Obligasi & 1 & $1 \%$ \\
& Lainnya & 6 & $6 \%$ \\
\hline
\end{tabular}


Berdasarkan karakteristik dana yang dialokasikan untuk pendidikan anak, sebanyak $63 \%$ responden menyisihkan $<20 \%$ penghasilannya. Ada beberapa alasan yang menyebabkan ibu rumah tangga menyisihkan $<20 \%$ seperti dana yang ada dialokasikan untuk kebutuhan sehari-hari, kebutuhan usaha, dan alasan lainnya. Sedangkan sebanyak 37\% responden ibu rumah tangga mengalokasikan $\geq 20 \%$ dari penghasilan yang ada. Alasan yang menyebabkan mengalokasikan $\quad \geq 20 \%$ diantaranya menganggap pendidikan penting bagi anak, biaya pendidikan yang terus meningkat dan alasan lainnya. Berdasarkan sosialisasi OJK, keluarga sebaiknya menyisihkan dana pendidikan anak sebesar $20 \%$ dari penghasilan (Otoritas Jasa Keuangan, 2013:47). Hal tersebut dirasa perlu karena mengingat biaya pendidikan yang dari tahun-ketahun terus meningkat yaitu kisaran $15 \%$ sampai $20 \%$.

Karakteristik instrumen yang dimanfaatkan untuk mengalokasikan perencanaan dana pendidikan, yang paling banyak dimanfaatkan adalah tabungan umum yaitu sebanyak $59 \%$ hal ini sendiri dikarenakan ibu rumah tangga cendrung memanfaatkan tabungan umum untuk perencanaan jangka pendek, hal ini terbukti dari alasan diantaranya seperti faktor kemudahan mengambil apabila dibutuhkan sewaktu-waktu atau faktor liquiditas, kemudahan minyimpan uang dan keamanan, perencanaan jangka pendek adalah perencanaan yang jangka waktunya kurang dari satu tahun (Kapoor et al, 2011). Untuk urutan kedua instrumen yang digunakan adalah asuransi pendidikan sebanyak 35\%, alasan menggunakan asuransi pendidikan diantaranya seperti proteksi, dan adanya kompensasi ketika tahun ajaran baru. Selain beberapa alasan tersebut faktor pendapatan rumah tangga yang masih tergolong kelas menengah ikut mempunyai peran dalam mengalokasikan dana pendidikan.

\section{Literasi Keuangan. Pengetahuan Keuangan Mengenai Perencanaan Keuangan Pada}

Dana Pendidikan Anak. Berikut ini adalah merupakan hasil uji deskriptif untuk melihat nilai rata-rata skor, nilai tertinggi dan nilai terendah dari pengetahuan keuangan mengenai perencanaan keuangan dana pendidikan anak. Pengetahuan keuangan dikatakan tinggi apabila skor nilai benar yaitu berada pada rata-rata skor $\geq 5$ dan rendah jika rata-rata skor nilai $<5$.

Tabel 9. Rata-rata Skor Pengetahuan Keuangan Mengenai Perencanaan Keuangan Pada Dana Pendidikan Anak

\begin{tabular}{lc}
\hline Kategori & Skor \\
\hline Rata-rata & 8,14 \\
Nilai Tertinggi & 10 \\
Nilai Terendah & 5 \\
\hline
\end{tabular}

Dari hasil perhitungan yang ada rata-rata skor tingkat pengetahuan keuangan mengenai perencanaan keuangan pada dana pendidikan anak dikalangan ibu rumah tangga yaitu kisaran 8,14, skor ini termasuk kategori tinggi karena diatas skor $\geq 5$. Hal ini dikarenakan tingkat pendidikan ibu rumah tangga yang menjadi responden pada penelitian ini sebagian besar lulusan SMA dan S1. Lusardi dan Mitchell (2014) menemukan dimana semakin tinggi tingkat pendidikan maka semakin tinggi pengetahuan keuangan. Dengan tingkat pengetahuan keuangan yang memadai maka akan memudahkan ibu rumah tangga untuk membuat keputusan keuangan mengenai perencanaan keuangan pada dana pendidikan anak. 
Keputusan Keuangan Mengenai Perencanaan Keuangan Dana Pendidikan. Berikut ini adalah hasil perhitungan untuk melihat persentase keputusan keuangan mengenai perencanaan keuangan dana pendidikan.

Tabel 10. Keputusan Keuangan Mengenai Perencanaan Keuangan Dana Pendidikan

\begin{tabular}{llcc}
\hline No & Keterangan & Ya & Tidak \\
\hline 1 & $\begin{array}{l}\text { Menetapkan tujuan yang hendak dicapai pada saat membuat } \\
\text { perencanaan dana pendidikan anak }\end{array}$ & $94 \%$ & $6 \%$ \\
2 & $\begin{array}{l}\text { Melakukan perhitungan mengenai perkiraan biaya pendidikan } \\
\text { yang dibutuhkan dimasa depan }\end{array}$ & $70 \%$ & $30 \%$ \\
3 & $\begin{array}{l}\text { Melakukan evaluasi terhadap perencanaan dana pendidikan } \\
6\end{array}$ & $61 \%$ & $39 \%$ \\
\hline
\end{tabular}

Sebanyak 94\% responden pada penelitian ini sudah menetapkan tujuan yang hendak dicapai pada saat membuat perencanaan dana pendidikan anak. Seperti yang dikemukakan salah satu responden oleh Ibu Agustin (Mengurus rumah tangga, usia 48 tahun) pada wawancara yang dilakukan:

"Minimal pendidikan anak yaitu S1".

Hampir sama dengan yang dikemukakan Ibu Veronika (Wirausaha, usia 53 tahun) dalam hasil wawancara yaitu :

"Minimal pendidikan anak S1, saya sudah bilang ke anak-anak kalau mau ambil S2 apabila mama bisa bantu mama bantu, bisa bekerja dulu karena S2 tidak dibatasi usia".

Dari hal tersebut dapat disimpulkan ibu rumah tangga sudah mengetahui tujuan yang hendak dicapai pada saat membuat perencanaan dana pendidikan anak. Menurut Goss (2001) dalam membuat perencanaan keuangan perlu menetapkan tujuan keuangan yang terukur. Sedangkan Kapoor, et al (2011) dalam membuat perencanaan keuangan dalam menetapkan tujuan keuangan perlu spesifik. Dengan menetapkan tujuan yang terukur dan spesifik maka akan memudahkan dalam menentukan perhitungan mengenai estimasi dana yang dialokasikan untuk perencanaan keuangan pada dana pendidikan anak.

Selanjutnya pada keputusan keuangan yaitu melakukan perhitungan mengenai perkiraan biaya pendidikan yang dibutuhkan dimasa depan kelak $70 \%$ responden sudah melakukan hal tersebut. Seperti yang dikemukakan oleh Ibu Agustin (Mengurus rumah tangga, usia 48 tahun) pada hasil wawancara:

"melakukan perkiraan misalnya skripsinya diluar kota berapa dana yang dibutuhkan seperti biaya kos, terus biaya study tour yang diadakan di kampus, apabila dana yang dianggarkan satu juta perlu dilebihkan guna berjaga-jaga apabila sakit".

Dari hal tersebut responden tidak hanya melakukan estimasi biaya kuliah namun biaya keperluan kuliah anak juga ikut diperkirakan. Selain itu ada juga responden yang sudah memperhitungkan mengenai perkiraan dana pendidikan anak sejak lima tahun sebelumnya, yaitu seperti dari hasil wawancara dengan Ibu Dwi (Mengurus rumah tangga, usia 54 tahun):

"Anak saya yang paling kecil kira-kira masih lima tahun lagi, paling tidak saya harus melipatkan dana tersebut dua kali lipat dari kakaknya".

Dari hal tersebut masing-masing ibu rumah tangga mempunyai cara yang berbeda-beda dalam melakukan perhitungan mengenai perkiraan perencanaan dana pendidikan anak, 
sedangkan $30 \%$ responden tidak melakukan perhitungan mengenai perkiraan biaya pendidikan yang dibutuhkan dimasa depan. Alasan tidak melakukan perhitungan mengenai perkiraan biaya pendidikan yang dibutuhkan dimasa depanseperti hanya melakukan perhitungan sampai anak SMA belum melakukan perhitungan sampai ke perguruan tinggi, sudah mengikutkan anak pada asuransi pendidikan sehingga hanya perlu membayar premi asuransi yang ditetapkan dan berbagai alasan lainnya.

Pada keputusan keuangan melakukan evaluasi terhadap perencanaan dana pendidikan anak sebanyak $61 \%$ responden sudah melakukan hal tersebut, contohnya seperti yang dilakukan salah satu responden yaitu melakukan evaluasi dari catatan keuangan yang ada. Sedangkan $39 \%$ responden tidak melakukan evaluasi mengenai perencanaan dana pendidikan anak. Berikut ini adalah salah satu alasan tidak melakukan evaluasi oleh Ibu Dwi (Mengurus rumah tangga, usia 54 tahun):

"Dulu itu sewaktu bapaknya kerja dan saya juga masih bekerja, saya merasa uang yang ada cukup untuk kedepannya, sehingga tidak perlu melakukan evaluasi”

Alasan perlunya melakukan evaluasi pada perencanaan keuangan yaitu seperti risiko inflasi, risiko suku bunga, risiko pendapatan, risiko individu, dan risiko likuiditas (Kapoor et al, 2011).

Perencanaan Keuangan Dana Pendidikan Anak. Berikut ini adalah hasil perhitungan rata-rata skor perencanaan keuangan pada dana pendidikan anak. Rata-rata skor perencanaan keuangan pada dana pendidikan anak dikatakan tinggi apabila $\geq 3$ dan dikatakan rendah apabila $<3$.

Tabel 11. Perencanaan Keuangan Dana Pendidikan Anak

\begin{tabular}{llc}
\hline No & Indikator & Rata-rata Skor \\
\hline 1 & Menganggap pendidikan tinggi penting bagi anak & 4,60 \\
2 & Mendanai kuliah anak dengan investasi yang sudah dipersiapkan & 4,23 \\
3 & $\begin{array}{l}\text { Menyisihkan kurang lebih 20\% dari penghasilan setiap bulan untuk } \\
\text { dana pendidikan anak }\end{array}$ & 4,21 \\
4 & $\begin{array}{l}\text { Mempersiapkan dana pendidikan anak sejak anak lahir } \\
5\end{array}$ & 4,22 \\
& $\begin{array}{l}\text { Melakukan estimasi biaya pendidikan yang dibutuhkan dimasa } \\
6\end{array}$ & 4,11 \\
& $\begin{array}{l}\text { Melakukan evaluasi terhadap perencanaan dana pendidikan anak } \\
\text { secara berkala }\end{array}$ & 3,96 \\
\hline & Rata-rata & 4,22 \\
\hline
\end{tabular}

Berdasarkan hasil perhitungan rata-rata skor perencanaan keuangan pada dana pendidikan anak yaitu 4,22 dapat dikategorikan tinggi karena berada diatas rata-rata skor 3, sehingga berada pada skala setuju. Rata-rata skor tertinggi terdapat pada indikator satu yaitu menganggap pendidikan tinggi penting bagi anak yaitu sebesar 4,6.Hal ini mengindikasikan bahwa orang tua mulai menyadari pentingnya pendidikan tinggi bagi anak sebagai bekal bagi anak dimasa depan. Hal ini terbukti pada keputusan keuangan dari hasil wawancara kepada responden yang telah menetapkan target minimal pendidikan anak adalah $\mathrm{S} 1$.

Pada indikator selanjutnya mendanai kuliah anak dengan investasi yang sudah dipersiapkan yaitu dengan rata-rata skor 4,23. Beberapa responden sudah mempersiapkan 
dana pendidikan anak dalam bentuk tabungan umum, asuransi pendidikan, tabungan pendidikan dan instrumen lainnya. Sedangkan pada indikator ketiga yaitu menyisihkan kurang lebih $20 \%$ dari penghasilan setiap bulan untuk dana pendidikan anak dengan ratarata skor 4,21 artinya para ibu rumah tangga yang menjadi responden pada penelitian ini setuju dengan hal tersebut, namun pada prakteknya hanya sekitar $37 \%$ ibu rumah tangga yang sudah mengalokasikan $\geq 20 \%$ dari penghasilan. Hal ini dikarenakan sebagian responden beralasan dana yang ada dialokasikan untuk kebutuhan sehari-hari, kebutuhan usaha, dan alasan lainnya, selain itu jika dilihat dari penghasilan rumah tangga yang ada masih berada pada rentangan kelompok kelas menengah.

Pada indikator ke empat yaitu mempersiapkan dana pendidikan anak sejak lahir berada pada kisaran skor 4,22, artinya rata-rata ibu rumah tangga setuju untuk mempersiapkan dana pendidikan anak sejak lahir. Dana pendidikan anak sendiri perlu dipersiapkan jauh-jauh hari mengingat biaya pendidikan yang terus meningkat dan supaya tidak terlalu mendesak dalam hal mempersiapkan biaya pendidikan tersebut kedepannya. Selanjutnya untuk indikator ke lima yaitu melakukan estimasi biaya pendidikan berada pada rata-rata skor 4,11 dan indikator keenam melakukan evaluasi terhadap perencanaan dana pendidikan anak secara berkala berada pada rata-rata skor 3,96 berarti rata-rata ibu rumah tangga setuju dengan melakukan estimasi biaya dan melakukan evaluasi pada perencanaan dana pendidikan anak. Bila dilihat dari hasil wawancara pada keputusan keuangan perencanaan dana pendidikan anak, ada beberapa hal yang dilakukan oleh beberapa responden yaitu seperti tidak hanya memperkirakan biaya kuliah anak namun biaya kebutuhan kuliah dan melakukan perencanaan keuangan lima tahun sebelum anak kuliah, yang selanjutnya melakukan evaluasi terhadap catatan keuangan yang ada. Sehingga dari rata-rata skor perencanaan keuangan pada dana pendidikan anak dapat disimpulkan ibu rumah tangga menganggap penting hal tersebut.

\section{PENUTUP}

Literasi keuangan pada ibu rumah tangga tergolong tinggi, hal ini dikarenakan faktor pendidikan ibu rumah tangga sebagian adalah lulusan SMA dan Sarjana, namun hal ini berbanding terbalik dengan karakteristik perencanaan dana pendidikan anak, masih banyak ibu rumah tangga yang mengalokasikan dana pendidikan kurang dari $20 \%$ dari penghasilan yang ada, hal ini dikarenakan faktor pendapatan rumah tangga yang berada dikelas menengah sehingga penghasilan yang ada di alokasikan untuk kebutuhan seharihari, usaha dan lainnya.

Perencanaan keuangan pada dana pendidikan anak dianggap penting oleh kalangan ibu rumah tangga, diantaranya seperti pada hasil wawancara beberapa ibu rumah tangga sudah menetapkan tujuan keuangan sampai perguruan tinggi sehingga dari hal tersebut ibu rumah tangga menganggap pendidikan tinggi penting bagi anak, ibu rumah tangga juga sudah melakukan estimasi mengenai biaya pendidikan dimasa depan dan melakukan evaluasi mengenai perencanaan keuangan pada dana pendidikan anak.

Implikasi Terapan. Perencanaan keuangan pada dana pendidikan anak merupakan hal yang penting, mengingat pendidikan adalah bekal bagi anak dimasa depan dan biaya pendidikan anak yang terus meningkat tiap tahunnya, oleh sebab itu perlu merencanakan dana pendidikan anak dari sejak dini agar tidak terlalu membebani kedepannya. Selain itu, mengalokasikan dana untuk perencanaan keuangan pada pendidikan anak sebaiknya ibu rumah tangga menyisihkan sebesar $20 \%$ dari penghasilan, mengingat biaya pendidikan 
yang mengalami kenaikan kisaran $15 \%$ sampai $20 \%$ tiap tahunnya. Dalam membuat perencanaan keuangan pada dana pendidikan anak juga pastinya ada risiko yang mungkin terjadi seperti risiko inflasi, risiko suku bunga, risiko pendapatan, risiko individu, dan risiko likuiditas, oleh sebab itu perlu melengkapi perencanaan dana pendidikan anak dengan proteksi asuransi guna menghindari risiko yang terjadi.

Saran. Keterbatasan penelitian ini yaitu mengenai kualitas data yang belum bisa digali sempurna, hal ini sendiri karena belum terciptanya probing antara peneliti dan responden. Sehingga saran untuk penelitian selanjutnya peneliti bisa menggali informasi dengan metode wawancara dengan melakukan probing terlebih dahulu antara peneliti dan responden supaya terjalin komunikasi yang baik, sehingga terjadi keterbukaan oleh responden dan kualitas data dapat digali dengan sempurna.

\section{DAFTAR PUSTAKA}

Akbar, A. (2007) Cara Kaya Dengan Investasi. Jakarta: Rabka Publisher.

Badan Kependudukan dan Keluarga Berencana Nasional. (2013) Aktifkan Kembali Kampanye Dua Anak Cukup. (Retrifed from: http://www.bkkbn.go.id/).

Badan Pusat Statistik Salatiga. (2013) Data Pembangunan Salatiga Tahun 2013. (Retrifed from: http://st2013.bps.go.id/st2013esya/booklet/st3373.pdf).

Behrman, J.R., O.S. Mitchell, C.K. Soo, dan D. Bravo. (2012) The Effects Of Financial Education And Financial Literacy: How Financial Literacy Affects Household Wealth Accumulation. American Economic Review: Paper and Proceedings.

Byrne, A. 2007. Employee Saving and Investment Decisions in Defined Contribution Pension Plans: Survey Evidence from the U.K. Financial Services Review 16 (2007) 19-4.

Chen, H dan R. P. Volpe. 1998. An Analysis of Personal Financial Literacy Among College Students. Financial Service Review. 11: 289-307.

Goss, B. 2001. 11 Top Financial Planning Mistakes And How To Avoid Them Chiropractic Economics.(Retrifed from: http://www.chiroeco.com/article/1999/Nov/Fin2.php.).

Hailwood, K dan D. Widdowson. 2007. Financial literacy and its role in promoting a sound financial system. Reserve Bank of New Zealand. 70 (2). (Retrifed from: http://www.reservebank.govt.nz/research_and_publications/reserve_bank_bulletin /2007/2007jun70_2widdowsonhailwood.pdf).

Hanafi, I. 2007. Faktor-Faktor Yang Mempengaruhi Minat Nasabah Dalam Memanfaatkan Fasilitas Pembiayaan Pada BMT Amratani Yogyakarta. Skripsi. Universitas Islam Kalijaga: Yogyakarta.

Kapoor, J.R., L.R. Dlabay, dan Hughes, R.J. 2011. Personal Finance. New York: Mc Graw Hill.

Kementrian Dalam Negeri Republik Indonesia Direktoral Jendral Pemberdayaan Masyarakat Dan Desa. 2012. Data Pokok Desa (Retrifed from: http://prodeskel.binapemdes.kemendagri.go.id/dpokok_grid_t01/).

Krishna, A., R. Rofaida., dan M, Sari. 2010. Analisis tingkat literasi keuangan di kalangan mahasiswa dan faktor-faktor yang mempengaruhinya (Survey pada Mahasiswa Universitas Pendidikan Indonesia). Proceedings of The 4th International 
Conference on Teacher Education; Join Conference UPI \& UPSI Bandung, Indonesia, 8-10 November 2010.

Lusardi, A dan O.S. Mitchell. 2014. The Economic Importance of Financial Literacy: Theory and Evidence. Journal of Economic Literature 2014, 52(1), 5-44

Margaretha, F. dan R. A.,Pambudhi.. 2015. Faktor-Faktor Yang Mempengaruhi Literasi Finansial Mahasiswa Fakultas Ekonomi dan Bisnis Universitas Brawijaya. Jurnal Akuntansi dan Pendidikan 1 (1).

Navickas, M., T. Gudaitis dan E. Krajnakova. 2014. Influence Of Financial Literacy On Management Of Personal Finance In A Young Household. Business: Theory and Practice 15 (1):32-40.

Otoritas Jasa Keuangan. 2013. OJK Perkuat Upaya Inklusi dan Perluasan Akses Keuangan Melalui Literasi Keuangan. Majalah OJK Edisi November. (Retrifed from: http://sikapiuangmu.ojk.go.id/public/content/files/Majalah-OJK-2.pdf.).

Otoritas Jasa Keuangan. 2013. Perencanaan Keuangan Ibu Rumah Tangga. (Retrifed from:http://sikapiuangmu.ojk.go.id/public/content/files/bukuperencanaankeuanganirt.pdf.)

Otoritas Jasa Keuangan. 2015. Strategi Nasional Literasi Keuangan Indonesia. (Retrifed from:http://sikapiuangmu.ojk.go.id/public/content/files/Materi\%20Eduwan/2\%20E duwan\%20Malang\%20\%20Materi\%20Strategi\%20Nasional\%20Literasi\%20Keua ngan\%20Indonesia\%20(Bu\%20Ria\%20Prastiani).pdf).

Praditya, I. I. 2014. Ibu Rumah Tangga Jadi Incaran OJK. (Retrifed from:http://bisnis.liputan6.com/read/2014391/ibu-rumah-tangga-jadi-incaran-ojk.

Pritazahara, R. dan U. Sriwidodo. 2015. Pengaruh Pengetahuan Keuangan Dan Pengalaman Keuangan Terhadap Perilaku Perencanaan Investasi Dengan Self Control Sebagai Variabel Moderating. Jurnal Ekonomi dan Kewirausahaan. 15 (1).

Rasyid, R. 2012. Analisis Tingkat Literasi Keuangan Mahasiswa Program Studi Manajemen Fakultas Ekonomi Universitas Negeri Padang. Jurnal Kajian Manajemen Bisnis. 1 (2).

Rini, M. 2006. 120 Cara Mengelola Keuangan Pribadi. Elex Media Komputindo, Jakarta.

Rosaline, G. A. 2014. Alokasi Pendapatan Dan Literasi Keuangan (Studi Empiris Pada Ibu Rumah Tangga di Kelurahan Panggung Lor, Kecamatan Semarang Utara, Kota Semarang). Universitas Kristen Satya Wacana Salatiga.

Sekretariat Kabinet Indonesia. 2015. Pemerintah Hapus Ketentuan Pencairan JHT Dibayarkan Saat Usia Peserta Capai 56 Tahun. (Retrifed from: http://setkab.go.id/pemerintah-hapus-ketentuan-pencairan-jht-dibayarkan-saatusia-peserta-capai-56-tahun/).

Sembel, R., M. Ichsan dan P. Lubis. 2003. Smart Saving and Borrowing for Ordinary Family. Jakarta : Elex Media Komputindo.

Senduk, S. 2000. Mengelola Keuangan Keluarga, Seri Perencanaan Keuangan Keluarga. Jakarta : Elex Media Komputindo. . 2007. Mempersiapkan Dana Pendidikan Anak. Jakarta : Elex Media Komputindo. .2008. Mengatur Pengeluaran Secara Bijak. Jakarta: Elex Media Komputindo Kelompok Kompas Gramedia.

Septiani, N., dan M. R. Rita. 2013. Melek Finansial dan Spending Habits Berdasarkan Jenis Kelamin (Studi Empiris Pada Mahasiswa/i di FEB UKSW).Salatiga ; Universitas Kristen Satya Wacana. 
Suhartini, D., dan J. A. Renanta. 2007. Pengelolaan Keuangan Keluarga Pedagang Etnis Cina. Jurnal Riset Ekonomi dan Bisnis. 7 (2).

Supramono dan I. Utami. 2004. Desain Proposal Penelitian Akuntansi dan Keuangan. Yogyakarta: Andi.

Unola, E., dan N. Linawati. 2014. Analisa Hubungan Faktor Demografi Dengan Perencanaan Dana Pendidikan dan Dana Pensiun Pada Masyarakat Ambon. FINESTA. 2 (2):29-34.

Wibawa, H.K. 2003. Perencanaan Keuangan Keluarga. Jakarta : Salemba Empat.

Widiatmanti, H. 2015. Penghasilan Kelas Menengah Naik = Potensi Pajak?. (Retrifed from: http://www.bppk.kemenkeu.go.id/publikasi/artikel/167-artikel-pajak/21014penghasilan-kelas-menengah-naik-potensi-pajak).

Widiyanto, Y., dan A. Husaini. 2010. Biaya Pendidikan Naik 20\% Setahun, Siapkan Sejak Dini! (Retrifed from: http://personalfinance.kontan.co.id/news/biaya-pendidikannaik-20-setahun-siapkan-sejak-dini--1).

Widiyati, I. 2012. Faktor-Faktor yang Mempengaruhi Literasi Finansial Mahasiswa Fakultas Ekonomi dan Bisnis Universitas Brawijaya. Jurnal Akuntansi dan Pendidikan. 1 (1).

Widodo, S. R. 2015. Siaran Pers : Kembangkan Literasi Keuangan OJK Gelar Seminar Internasional. (Retrifed from: http://www.ojk.go.id/siaran-pers-kembangkaninovasi-literasi-keuangan-ojk-gelar-seminar-internasional).

Wijaya, T. 2012. Cara Cepat Menguasai SPSS 20. Yogyakarta : Cahaya Atma Pustaka.

Yamane, T. 1973. Statistic an Introductory Analysis, Third Edition. Tokyo: Aoyama Gakuin University.

Yohnson. 2004. Peran Universitas di Surabaya dalam Meningkatkan Jumlah Keluarga Mapan di Surabaya . Jurnal Manajemen \& Kewirausahaan. 6 (1): 54 - 71.

Yulianti, N dan M. Silvy. 2013. Sikap Pengelolaan Keuangan Dan Perilaku Perencanaan Investasi Keluarga Di Surabaya. Journal of Business and Banking. 3 (1): 57 - 68. 